\title{
The Early Days of Computer Aided Newspaper Production Systems
}

\author{
Nils Enlund ${ }^{1}$ and Hans E. Andersin ${ }^{2}$ \\ ${ }^{1}$ Royal Institute of Technology (KTH), Sweden \\ nilse@kth.se \\ ${ }^{2}$ Helsinki University of Technology, Finland \\ hans.andersin@hut.fi
}

\begin{abstract}
During the years 1970-1973, the Laboratory of Information Processing Science at the Helsinki University of Technology carried out the Computer Graphics Project (CGP). The activities focused on the problems of producing newspaper text, advertisements, and complete pages using interactive computer graphics. The project and its commercial spin-off, Typlan, as well as the BUNPAPS continuation project 1973-1975, created a number of innovative, pioneering solutions for computer aided newspaper production, laying the foundation for the digitalization of media production.
\end{abstract}

Keywords: Newspaper production, page layout, text processing.

\section{Computer Aided Newspaper Production in the Early 1970s}

The 1960s were a time of great changes in newspaper production, an industrial sector that hitherto had been characterized by traditional technology and a production process with roots in Gutenberg's time. Offset presses that allowed high quality fourcolor printing were replacing letterpress printing presses. Offset also required the replacement of metal printing forms with photographically produced printing platesa technology that paved the way for photocomposing machines, color separating image scanners, and page assembly by cutting and pasting film. Text galleys were still produced in manually controlled typecasting machines although a few printing companies already in 1957 had installed perforated tape readers to control the type casters. The speed had limitations, however, by the fact that the punch operators had to break their pace after every thirty or so characters to end the line and possibly hyphenate a word. The solution to this was the use of computer-based hyphenation and justification $(\mathrm{H} \& \mathrm{~J})$ systems that took unjustified text on perforated tape as input and produced a justified output tape with inserted hyphens and line endings. The first trials with computerized typesetting occurred in 1962 in the USA [24] and in 1965, IBM introduced hyphenation and justification software for its 1130 minicomputer [28].

In the Nordic countries, the Finnish newspaper Turun Sanomat was a pioneering user of computers in newspaper production. In 1964, the first H\&J system in Europe, using an IBM 1401 computer, was installed. The system initially produced punched tape for controlling hot metal typesetters but in 1967, Turun Sanomat purchased the first photocomposition machine in Finland [20,21]. The first photo composer in 
regular newspaper production, a Photon 100, had been installed already in 1954 at the Quincy Patriot Ledger, although hot metal line casting machines remained in use at many newspapers for many years to come [27].

In 1970, more than fifty companies were delivering composition systems to the graphic arts industry, most of them North American [22]. The British manufacturer Comprite installed several newspaper systems, based on the PDP-8 minicomputer from Digital Equipment Corporation, in the Nordic countries, e.g., to Hufvudstadsbladet in Finland in 1969 [19]. In Norway, Comtec, a university spin-off, produced a similar paper-tape-in paper-tape-out system. In 1969, Hendrix Electronics introduced the $5102 \mathrm{FD} \mathrm{H} \& \mathrm{~J}$ system that allowed text input from paper tape to be displayed and edited on the screen of a video display terminal (VDT) prior to the output of justified paper tape.

A special problem was the computer-aided production of display advertisements, i.e., ads with a complex typographical design where many fonts and type sizes are used and where the text must be placed and adjusted to fit graphics in the ad. At the beginning of the 1970s, this type of ads could only be produced by separately composing the different text elements and then assembling them manually according to the advertiser's layout sketches. However, in 1972, Harris Corp. introduced an interactive VDT based ad composition system, Harris 1100. The screen would show an image in simulated stick characters of the ad as it would look when typeset. If the image did not conform to the layout sketch, the operator modified the typographical codes until she was satisfied with the result. The system then produced a punched tape for the photo composer. They manually pasted graphics. At the time, photo composers could only produce rather narrow film. Consequently, text blocks were set sequentially, cut out, and mounted according to the ad layout.

In 1970, the research institute of the American Newspaper Publishers' Association developed a computer program, LAYOUT, for the automatic planning of the placement of ads on newspaper pages [9]. They fed the dimensions of the ads on punched tape into an IBM 1130 where a FORTRAN program placed the ads in pyramid form on page templates. Layout sketches were output on a line printer and they became a basis for manually making up pages. The company Rocappi designed a system for automatic page make-up of simple book pages already in 1964 using an RCA 301 computer. British Printing Corporation developed during 1969-70 a prototype system for interactive layout of magazine pages [29]. The system used an IBM 1130 and an IBM 2250 interactive vector graphics terminal. The project was discontinued in 1970 and no one ever implemented the ideas.

\section{Computer Graphics Project}

\subsection{Objectives and Resources}

In 1968, Hans Andersin was appointed to the first chair of Information Processing Science at the Helsinki University of Technology. After a feasibility study financed by SITRA, The Finnish National Fund for Research and Development, Andersin initiated a research and development project, supported by SITRA and two major Finnish newspaper companies, Helsingin Sanomat and Turun Sanomat. The project 
was called the "Computer Graphics Project" (CGP). SITRA funded CGP for the period from February 1970 to September 1971. The Bank of Finland mainly financed the computer equipment [1]. The aim was to develop internationally marketable applications in the field of text processing, and the focus was on developing principles and prototypes for page make-up systems, editorial systems and document handling systems [3].

Digital Equipment Corporation provided laboratory equipment built around a PDP15 computer. PDP-15 had a word length of 18 bits and was the first DEC computer using integrated circuits instead of discrete transistors. A separate input/output processor enhanced the performance of the system. The first delivered PDP-15 was installed at CGP in February 1970. The PDP-15/30 was equipped with a $20 \mathrm{MB}$ DECdisc RP15/RP02, and with DEC's proprietary magnetic tape storage, DECtape. It also had a punched tape reader for the input of programs and data. The paper tapes were key-punched on a Teletype ASR-33. Programming was made in assembler. According to the "zeitgeist" of that time, the project staff soon decorated the CGP computer with a large peace symbol and it was nicknamed Mirri (in Finnish, mirri means pussycat and in Russian, mir stands for peace; see Figure 1).

The main interaction tool was an ARDS 100A VDT using a storage screen. The terminal drew vector objects between points on the screen in the manner of a plotter. The advantage of this was that all lines, regardless of angle, were sharp. The disadvantage was that character fonts had to be represented by stick characters and that raster pictures could not be presented at all. Another peculiarity was the long time constant of the CRT phosphorus: a once drawn figure remained visible on the

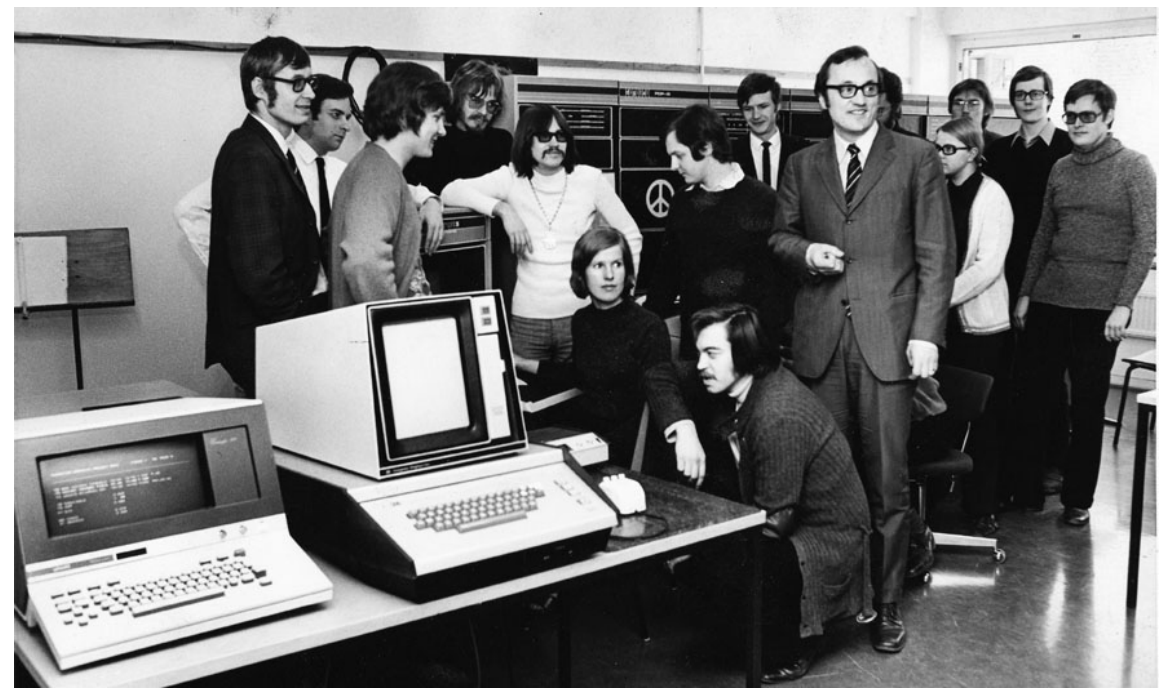

Fig. 1. The PDP-15 of CGP and part of the project staff. The authors of this paper are numbers five (Enlund) and ten (Andersin) from the left. 
screen for a long time. To change the picture, it was necessary to wipe the entire screen and redraw the picture. The terminal had a primitive mouse for addressing points on the screen. Later, CGP acquired a DEC Graphic-15 system with a VT04 raster scan screen and a separate graphic processor. User interaction was by light pen or tablet.

\subsection{Computer Aided Page Make-Up}

One objective of CGP was to develop a system for interactive planning and make-up of newspaper and magazine pages. Initially, two separate solutions were planned, INEInteractive Newspaper System - and IMA - Interactive Magazine System. Soon, however, the focus was directed toward the problems of newspaper page production. This was considered to pose a more interesting challenge because of the tight time constraints in the daily production cycle. Before long, it became clear that the ambitions were too high with respect to the available time and resources. The project therefore concentrated on defining detailed systems specifications for the INE and IMA systems and on designing a prototype system that would demonstrate the design concepts.

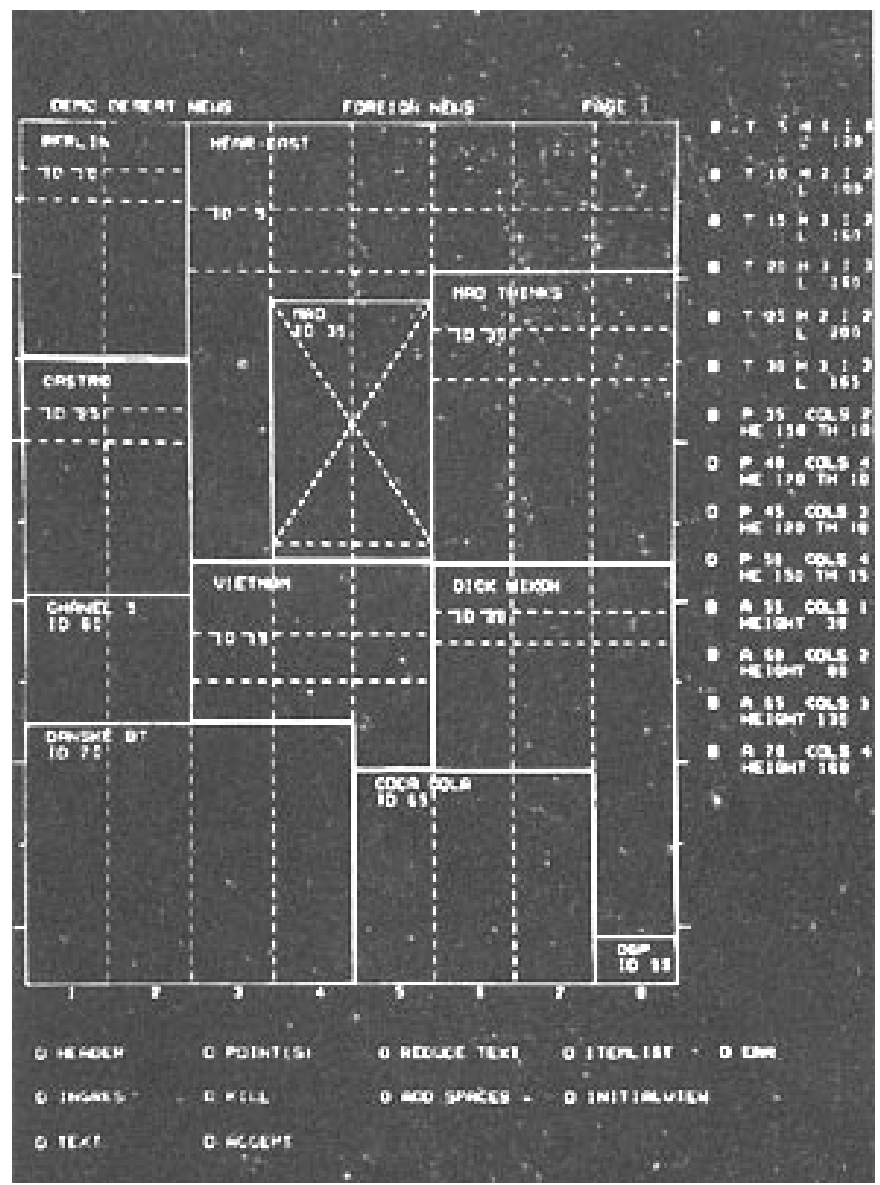

Fig. 2. Page make-up in the JANDMO system 
This demonstrator was called JANDMO — short for January Demonstration System, since the solutions were to be shown to partners and funding organizations in January 1971. Because of delays in the delivery of the Graphic-15, they could not keep the deadline, but in February 1971, the first working prototype of a computer system for interactive make-up of newspaper pages was demonstrated to an enthusiastic audience.

JANDMO would let the user call up a list of available stories on the screen. From this list, the operator selected stories for proofreading and editing. He/she could assign a set of stories to a certain page, e.g., the sports page. An empty template, with only column guides visible, representing the page was then called up on the screen. The operator then interactively placed different text blocks of the stories-headline, lead-in, galley text-in the desired positions on the page (Figure 2). He/she divided the galley text into columns using a light pen to cut off the galley and move the tail end into the next column. The size estimates were approximate since no exact justification or hyphenation was possible. They represented ads and graphics by rectangular space reservations. The output from the system was layout sketches.

\subsection{Display Ad Production}

The CGP also developed a composing system for display advertisement where the user did the design of the ad interactively instead of by typographical encoding. In the IDA (Interactive Ad Design) system, the text blocks of an ad were named during text input - on punched tape or on the display screen. On the VDT, the shape of each text block was drawn, named, and placed interactively. The software then connected each block with the corresponding text, justified and hyphenated the text to fit the shape, and displayed the composed text using simulated characters. Corrections and adjustments had to be made by entering typographical commands into the text strings and repeating the process. Finally, the system produced a punched tape for a photo composer that exposed the composed text blocks in one single operation. Images and graphics then had to be pasted in manually.

The IDA system was an advanced precursor to the commercial ad production system produced by Harris Corp. in 1972 and which was to become the standard for display ad composition for many years to come. However, it took a long time before interactive ad design was implemented in professional systems.

\subsection{Text Processing}

A basic problem that had to be solved early in the CGP project was the automated hyphenation and justification $(\mathrm{H} \& \mathrm{~J})$ of text. In order to obtain a correct composition of lines on text, algorithms had to be developed for calculating the number of characters, in different fonts and point sizes, to be placed on each line of composed text, for dividing words according to the hyphenation rules of each language, and for distributing space evenly between words to fill the lines. The algorithms could then be used in all text-processing applications. 


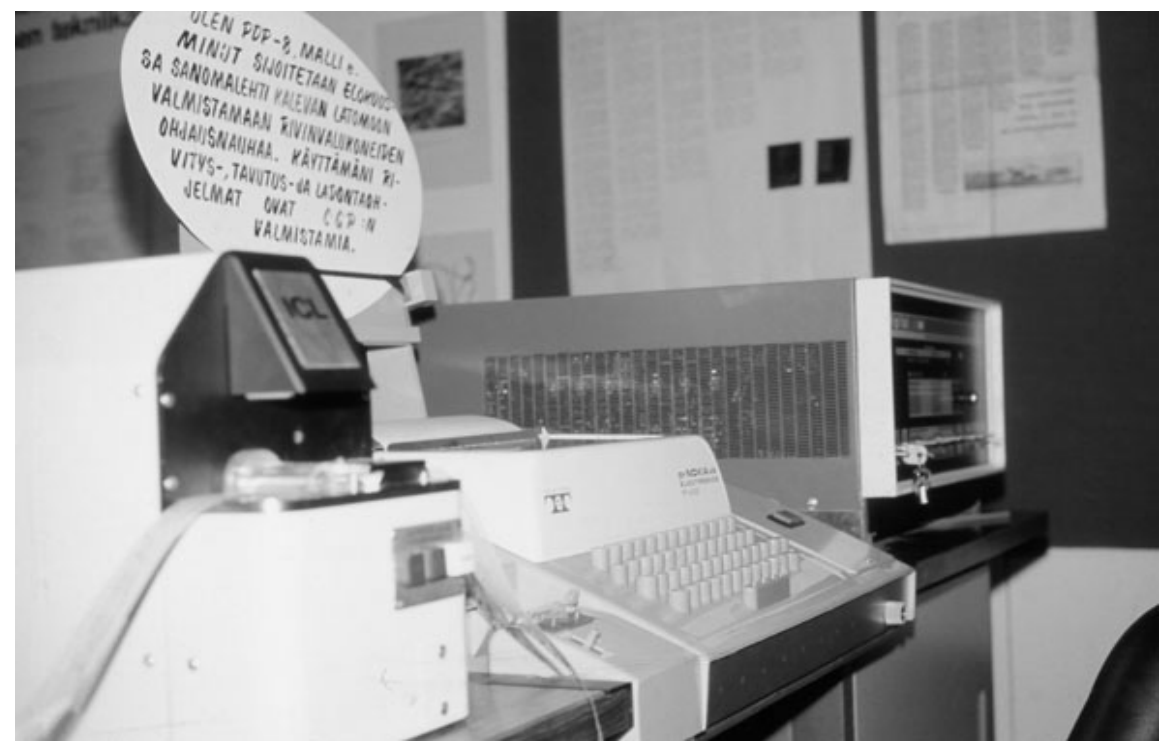

Fig. 3. The PDP-8/e based hyphenation and justification system at Kaleva

In 1970, CGP received a proposal from the newspaper company Kaleva to develop a simple H\&J system for the production of galleys by tape-driven hot metal typesetting machines. In spring 1971, they built a system for the PDP-8 minicomputer (Figure 3). The entire software, including control and interrupt handling routines as well as input and output drivers, was crammed into the available $4 \mathrm{~K}$ of 12 -bit core memory. The system first used expanding space bands for justifying the lines in the typesetter but later had algorithms for justification without space bands-a more calculation intensive method that required the core memory to be expanded to 8K [30]. CGP had now found a commercially attractive product that they could sell immediately to other newspapers.

\subsection{Integrated Newspaper Production Systems}

The ambitions of CGP were high, aiming at designing and implementing an integrated computer based newspaper production system with a wide spectrum of functions such as text input, interactive editing, $\mathrm{H} \& \mathrm{~J}$, production of classified ads, composition of tables, display ad make-up, full page make-up, output of proofs and layout sketches, and online output to photo composers. The project could deliver proof-of-concept for many of these functions during the short project duration but newspapers would have to wait many years for such integrated newspaper systems.

Such an integrated production system must be built around a common database (Figure 4). Jules Tewlow first presented this idea in 1968 [31], but CGP was a pioneer in taking concrete steps toward an implementation. The vision of a totally integrated newspaper production system has not yet occurred. Instead, most newspaper production systems consist of a patchwork of systems and software from different manufacturers. 


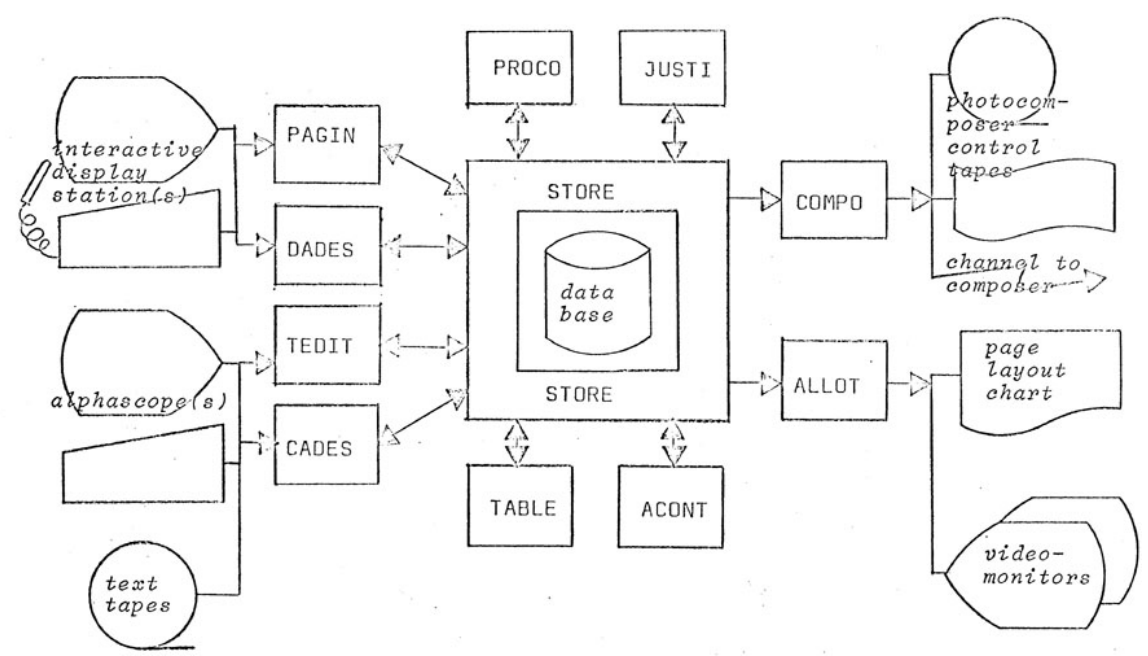

Fig. 4. The principles of an integrated text processing system for newspapers [22]

\subsection{Continuation Projects}

The SITRA funding ceased during the fall of 1971. The financing of CGP continued by means of minor commissioned projects and with earnings from commercial activities. A significant source of funding was Nordisk Avisteknisk Samarbetsnämnd (Nordic Newspaper Technology Association).

Research aiming at developing interactive newspaper production systems continued during 1971 and 1972 [4]. The group built an editorial system, SCANEX, for the PDP15 computer and a Delta Telterm-2 alphanumeric terminal (unfortunately without Scandinavian special characters). They installed the first similar commercial editorial system, Hendrix 3400, in 1972 at the Detroit News [28]. Other continuation projects included a study on the use of simulation to study and optimize the operations of a newspaper [23] and a project for automatic indexing and retrieval of text in a newspaper archive [10].

\section{Typlan: The Spin-Off Company}

The CGP funding agreement required commercialization of the results. In 1971, 15 of the CGP project staff jointly formed a company, Typlan Systems Projects Oy Ab. The, mostly young, CGP researchers and a few close supporters owned one share each in the company. This led to that the firm was considered as "our own" company; motivation was high, though they kept salaries and costs low. The main product of Typlan during the first year of operation was the simple punched tape based $\mathrm{H} \& \mathrm{~J}$ system developed for Kaleva. They also delivered similar systems to the Finnish newspapers Etelä-Saimaa, Hämeen Sanomat, Kymen Sanomat, Lapin Kansa, Satakunnan Kansa, and Savon Sanomat. The Finnish national news agency STTFNB installed a system for "teletypesetting" of text. 
The next product development step was to furnish the PDP-8 minicomputer with VDTs for online text entry and correction. Typlan's terminal based system was called Finntext and used VDTs from Hendrix and Delta Data. The first terminal based system in Finland was installed at the newspaper Hufvudstadsbladet in 1972. A few months earlier, the Norwegian company Comtec delivered the first similar system in Sweden to Värmlands Folkblad [19]. During summer 1973, Typlan installed a VDT based system at Keskisuomalainen in Finland. The earlier systems had had no means for storing the text files, but now they added disk storage. Typlan entered into cooperation with Hendrix Electronics Inc. and delivered VDT and database based systems to newspapers in the Swedish A-pressen chain. The enhanced Finntext system became a success and by the end of 1973, all the VDT and data base based typesetting systems in Finland were of this type [25].

The natural extension of the Finntext system was an adaptation to the requirements of newspaper editorial work. In the USA, the first experiments with text entry and editing by journalists had been carried out in 1972. The resistance from the journalists' union was solid. The European pioneer in editorial text processing was not a large newspaper publisher with strong negotiation muscles but, surprisingly enough, a very small local newspaper in Finland. The first editorial system in Europe was installed in 1974 at Tyrvään Sanomat, a local newspaper in Vammala that printed 8-10 broadsheet pages twice a week. The newspaper acquired a Finntext system consisting of a DEC PDP-8/e computer with $16 \mathrm{k}$ of core memory, 1.6 MB of disk storage, two Delta Telterm 5200 text terminals, a tape reader, and a line printer. The computer was connected online to a Compugraphics 4961TL photo composer. Part of the text content of the newspaper was punched on paper tape by composing room staff but a large part was input and edited directly on VDTs by journalists who also entered typographical commands. After hyphenation and justification, the text was output on a line printer and proofread. Corrections were entered on VDTs by composing room staff that also initiated output to the photo composer. The system worked well and newspaper executives from all over Europe came to visit the small town of Vammala. A similar system was soon installed at Etelä-Suomen Sanomat [26].

Typlan delivered a number of Finntext systems in Finland and Sweden during the early 1970s. It soon became apparent that the PDP-8 was not powerful enough to cope with the increasing systems demands: a larger number of online VDTs, larger databases, and increasing functionality. In 1974, Typlan decided to move to the more powerful PDP-11 minicomputer from DEC. The platform change required software porting and reprogramming. SITRA granted financial support for the product development effort. At the same time, Typlan departed from the principle that only staff and close supporters could own (equal) shares in the company and shares were issued to 16 of the company's customers. In 1975, the new line of newspaper production systems, the Typlan Text-11, including both composition and editorial functionality, was ready. Typlan had moved from a university research project to becoming an internationally competitive systems manufacturer.

\section{BUNPAPS}

While Typlan struggled with commercial applications, CGP-initiated research into interactive make-up of newspaper pages continued during 1973-75 at Brown 
University, USA. Hans Andersin and Nils Enlund were visiting researchers at Brown University, involved in a research project named Brown University Newspaper Page Production System, BUNPAPS. The U.S. State Department and an international group of newspaper companies funded the project: The New York Times, Dagens Nyheter, Providence Journal, Chicago Tribune, and Detroit News [7].

The objective of the project was to demonstrate the potential of interactive and algorithmic methods in newspaper page make-up. At this time, photo composers that could expose page-wide film had become available, and the idea was to increase productivity by outputting all text elements on a page in one single operation. Graphics would still have to be pasted in manually. Full-page output would be accomplished by first entering all text, including typographical commands, into a database. The text would be hyphenated and justified and the system would generate metadata on line endings and space requirements of the text blocks. This information would be input to page layout design software using heuristics and interactive graphics to create complete page layouts. The layout coordinates would then be merged with the actual text to control full-page output on a photo composer.

A prototype system was built around an IMLAC PDS-1D graphic workstation with a 16-bit processor, $8 \mathrm{k}$ of core memory, and a 13-inch vector graphics screen (Figure 5). Interaction was handled using keyboard and function keys. The workstation was connected to an IBM 360/67 timesharing system. The mainframe held the database and executed most of the calculations.

In the prototype, page make-up was based on actual text material. The space requirements of the text were calculated without performing actual H\&J. Only the outlines of rectangular blocks, linked to the text files, were shown on the screen. A text could flow between several linked blocks, from column to column, or from page to page. The text blocks were placed on a grid of columns on pages.

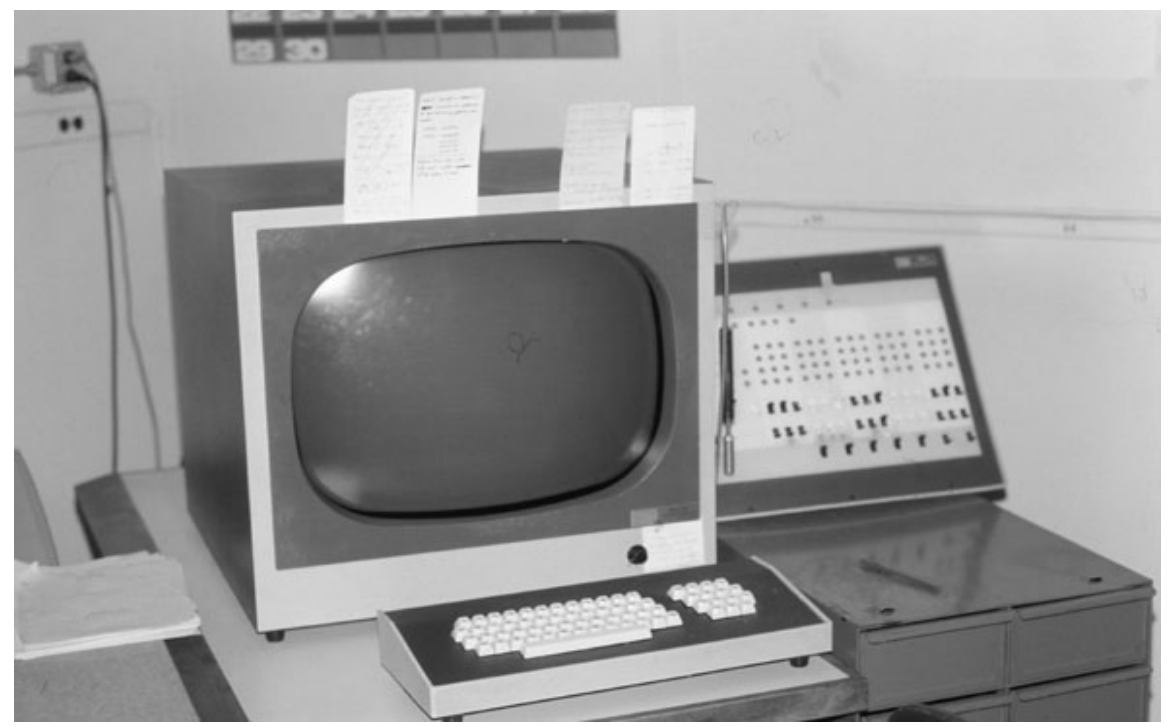

Fig. 5. The IMLAC PDS-1D graphic workstation of the BUNPAPS project 
The significant innovation in the BUNPAPS system was a set of methods for placing elements on a page that was developed, implemented, and tested $[5,6]$ :

Manual placement of single elements, where the operator would enter the page coordinates of the upper left hand corner of a text block. Placing a story partly on top of an already placed one would make the underlying text flow away to accommodate the new item.

"Intelligent" placement, where the operator would only give approximate, simple commands concerning the placement of a text, e.g., "as high up as possible", "in a rectangle at the bottom right", or "floating over the elements already placed at the bottom of the page". The heuristic algorithms would obtain as good a fit as possible under the given conditions. Laying out a page was very fast and the results were often quite good and aesthetically pleasing.

Template make-up was useful because certain types of newspaper pages tend to follow repeating, relatively well structured, but seldom explicitly defined design rules. Such pages can be laid out automatically. A set of alternative, flexible design template structures were defined based on an analysis of actual pages. The algorithm would propose a template that would fit the available items. The operator could choose to use an automatically generated layout or to modify one manually [11].

Holefilling is a method for the automatic placement of editorial items on such pages of a newspaper that are dominated by advertising, leaving only a relatively small "newshole" for editorial content. The heuristic algorithms would fill this space as efficiently as possible [14].

The BUNPAPS project demonstrated that computer aided page make-up was a viable concept that could speed up the newspaper page production process. The project was the starting point for the later development of commercial page make-up systems [12, 13]. The concepts were adopted by Hendrix (later Hastech) when developing the first commercially available newspaper page make-up system, PagePro [17].

\section{Consequences}

During the second half of the 1970s, the work of the original CGP team and its followers moved into the realm of product development and commercial applications. Typlan continued the development on the PDP-11 based, and later the VAX-11 based systems for the newspaper and commercial printing industry and became one of the main systems suppliers to the European graphic arts industry [18]. They brought the principles of computer aided page make-up back from the BUNPAPS project and the company embarked, in cooperation with the Swedish company Teragon, upon a project to create a total integrated publishing system, TIPS. This was never completed. The emergence in the mid-1980s of powerful personal computers with standardized text processing, image processing, and page make-up software eventually put an end to the vision of a centralized newspaper production system. Integrated networks of specialized subsystems on standard hardware platforms became the preferred technology. However, the pioneering innovations of the 1970s were later incorporated into modern newspaper systems $[15,16,17]$. In addition, the early production systems implemented at various newspapers prepared the Nordic newspaper industry for the coming digitalization of the page production process $[2,8]$. 
The staff of CGP, Typlan, and BUNPAPS eventually scattered. Some remained for many years with Typlan-Nokia later acquired the company-customers, competitors or other companies employed others, and some went into the academic world. Nevertheless, they all carried with them the creative enthusiasm of the pioneering years as well as a solid knowledge of systems design and of newspaper production. In addition to some of the central ideas of the projects, this might be the most important contribution of these early development efforts.

\section{References}

[1] Andersin, H.E.: CGP research in integrated newspaper systems, Laboratory of Information Processing Science, Helsinki University of Technology, Report 2/72 (1972)

[2] Andersin, H.E.: Textprocessing research - a service to the publishing industry. Data 6, 59-64 (1976)

[3] Andersin, H.E., Perilä, O., Perttula, P.: Interactive computer systems for the newspaper process. In: TAGA-71 Proceedings, Rochester (1971)

[4] Andersin, H.E., Hallivuori, M., Koski, T.H.A., Laaksonen, K., Leppämäki, K., Lundström, L.: System for computer aided newsproduction, Laboratory of Information Processing Science, Helsinki University of Technology, Report 1/72 (1972)

[5] Andersin, H.E., Enlund, N., Hopson, R., Millbrandt, W., Woodward, J.: Computer aided pagination of newspapers. In: TAGA -74 Proceedings, New York, pp. 230-247 (1974)

[6] Andersin, H.E., Enlund, N., Hopson, R., Millbrandt, W., Woodward, J.: Newspaper pagination by intelligent graphics. In: Automaatiopäivät-75 Proceedings, Espoo (1975)

[7] Andersin, H.E., Enlund, N., Millbrandt, W.: Pagination of newspages, Laboratory of Information Processing Science, Helsinki University of Technology, Report A-5/75, Espoo, 99 p. (1975)

[8] Andersin, H.E., Enlund, N.: Coping with technological change in publishing systems, PIRA Eurotype-Forum, Leatherhead (1977)

[9] Anon: LAYOUT computer program developed by ANPA/RI. ANPA/RI Bulletin 1075, 409-416 (1971)

[10] Björk, P.: Ett datorsystem för indexering och sökning i en dagstidnings klipparkiv, (A computer system for indexing and retrieval in a newspaper archive, in Swedish), MSc thesis, Laboratory of Information Processing Science, Helsinki University of Technology, Espoo (1973)

[11] Enlund, N.: Algoritmiska metoder vid paginering av tidningssidor (Algorithmic methods for newspaper pagination, in Swedish), MSc thesis, Laboratory of Information Processing Science, Helsinki University of Technology, Espoo, 104 p. (1974)

[12] Enlund, N.: Computer-aided layout design, Computer assisted page make-up. In: IFRA Symposium Report, IFRA, Darmstadt, 5 p. (1976)

[13] Enlund, N.: Computer aided page make-up. In: Computer Aided Printing and Publishing Conference Proceedings, London (1977)

[14] Enlund, N.: Improving man-machine communication using heuristic techniques. In: Interaktivnyje Sistemy, Akademija Nauk SSSR, Moscow, pp. 60-76 (1979)

[15] Enlund, N.: Electronic page make-up today, Special Report 129, IFRA, Darmstadt, 28 p. (1983)

[16] Enlund, N.: Electronic full page make-up—what took us so long? IFRA Newspaper Techniques, March 1990, pp. 7-12 (1990) 
[17] Enlund, N.: Electronic Full-Page Make-Up of Newspapers in Perspective, GutenbergJahrbuch 1991, Mainz, pp. 318-323 (1991)

[18] Enlund, N., Kallioja, T.: Tietokoneen käyttö lehden valmistuksessa (Using computers in newspaper production, in Finnish), Tutkimus ja tekniikka, Number 6 (1978)

[19] Friman, E. (ed.): Från handavdragspress till offsetrotation (From manual proofing press to offset rotary press, in Swedish), Hufvudstadsbladet: Helsingfors (1984)

[20] Järvi, T.: Computerized typesetting and other newspaper applications in a publishing house. In: Impagliazzo, J., Järvi, T., Paju, P. (eds.) History of Nordic Computing 2 (HiNC2). Springer, New York (2009)

[21] Kalpa, H.: Sanansaattajana Auran rannoilla - Turun Sanomat 1905-1985 (The messenger by river Aura - Turun Sanomat 1905-1985, in Finnish), Turun Sanomat: Turku (1984)

[22] Kautto, H., Perttula, P., Sulonen, R.: Interactive computer graphics as a new tool for newspaper editors, NordDATA-70, Copenhagen (1970)

[23] Koski, T.H.A., Louhenkilpi, T., Tuukkanen, A.: Simulating a newspaper system, Laboratory of Information Processing Science, Helsinki University of Technology, Report 2/73 (1973)

[24] May, J., Wrightson, W.S.: From lead to silicon-25 years of newspaper technology. In: IFRA, Darmstadt (1986)

[25] Palonen, O.: Tinapirusta toimitusjärjestelmiin - kun tietokone tuli lehtitalon sivunvalmistukseen (From printer's devil to editorial systems - when the computer entered newspaper page production, in Finnish). Tekniikan Waiheita 2, 20-29 (2005)

[26] Perttula, P.: Redaktionens och annonsavdelningens nya teknik för textinmatning, redigering och korrigering (New technology for text entry, editing and correcting in the editorial and advertising offices, in Swedish) 7:e Nordiska Tidningstekniska Konferensen, Lahti (1974)

[27] Perttula, P.: Kehittyvä tekstinkäsittelytekniikka, (Developing text processing technology, in Finnish). Insinööritieto Oy, Helsinki (1979)

[28] Seybold, J.W., Seybold, J.: Typesetting and pre-press technology. The Seybold Report on Publishing Systems 18, 3-23 (1985)

[29] Steuber, P.: A demonstration of magazine page layout using a graphic display terminal, Computer Graphics 70, Brunel University, Uxbridge (1970)

[30] Suistola, J.: Kaleva - sata vuotta kansan kaikuja (Kaleva - one hundred years as the voice of the people, in Finnish). Kaleva Kustannus, Oulu (1990)

[31] Tewlow, J.S.: Time-sharing and the newspaper of tomorrow: Part II - The newspaper of the future. ANPA R.I. Bulletin 951, 93-110 (1968) 